\begin{tabular}{llrr}
\hline \hline Volume: & 2 & E-ISSN: & $2655-1942$ \\
Number: & 2 & Terbitan: & November 2019 \\
Page : & $361-369$ & & \\
\hline
\end{tabular}

\title{
Pelanggaran Hak Tenaga Kerja Melalui Penahanan Ijazah Sebagai Jaminan
}

\author{
Muhamad Azhar, Ery Agus Priyono \\ Fakulats Hukum, Universitas Diponegoro \\ Corespondent Author: azhar@live.undip.ac.id
}

\begin{abstract}
Abstrak
Tulisan ini bertujuan untuk menguraikan terjadinya pelanggaran terhadap hak tenaga kerja melalui penahanan ijazah oleh subjek hukum tertentu. Subjek hukum yang dimaskud adalah penyandang hak dan kewajiban dalam rahan hukum ketenagakerjaan di Indoensia. Penelitian dilakukan dengan penanganan kasus secara langsung, dan melalui kajian konseptual. Kajian empiris terkait dengan kasus tersebut adalah yang merupakan klien dari Badan Konsultas Hukum Fakultas Hukum Universitas Diponegoro Semarang. Hasil kajian menjukan bahwa Tenaga Kerja sebagai pekerja dijamin melalui peraturan perundang undangan memiliki hak hak normatif, seperti hak untuk upah, jaminan sosial dan hak mendapatkan pekerjaan yang sesuai dengan keinginan. Penahanan ijazah oleh suatu sumbjek hukum baik indivisu ataupun perusahaan termasuk merupakan pelanggaran terhadap hak tenaga kerja. Pelanggaran terhadap hak tenagakerja tersebut berakibat pada adanya konsekuensi dari hubungan kerja antara keduabelah pihak. Maka hubungan kerja dapat dibatalkan jika ternyata penahanan ijazah benar adanya.
\end{abstract}

Kata Kunci: Hak Tenagakerja, Pelanggaran, Jaminan, Penahanan Ijazah

\section{Abstract}

This paper aims to describe the occurrence of violations of labor rights through the detention of diplomas by certain legal subjects. The subject of law included is the person with rights and obligations in labor law in Indonesia. Research is carried out by handling cases directly, and through conceptual studies. Empirical studies related to the case are those who are clients of the Law Consultant Board of the Faculty of Law, Diponegoro University, Semarang. The results of the study show that workers as workers are guaranteed through the legislation that have normative rights, such as the right to wages, social security and the right to get work as they wish. Detention of a diploma by an individual or company legal subject is a violation of labor rights. Violation of labor rights results in the consequences of employment relations between the two parties. Then the employment relationship can be canceled if it turns out the detention of a diploma is true.

Keywords: Labor Rights, Violations, Guarantees, Diploma Detention 


\begin{tabular}{llrr}
\hline \hline Volume: & 2 & E-ISSN: & $2655-1942$ \\
Number: & 2 & Terbitan: & November 2019 \\
Page : & $361-369$ & & \\
\hline
\end{tabular}

\section{A. Pendahuluan}

Tenaga kerja dalam pembangunan nasional mempunyai peranan dan kedudukan yang sangat penting sebagai pelaku dan tujuan pembangunan. Sesuai dengan peranan dan kedudukan tenaga kerja, diperlukan pembangunan ketenagakerjaan untuk meningkatkan kualitas tenaga kerja dan peran sertanya dalam pembangunan serta peningkatan perlindungan tenaga kerja dan keluarganya sesuai dengan harkat dan martabat kemanusiaan. Perlindungan terhadap tenaga kerja dimaksudkan untuk menjamin hak hak dasar pekerja/buruh dan menjamin kesamaan kesempatan serta perlakuan tanpa diskriminasi atas dasar apapun untuk mewujudkan kesejahteraan pekerja/buruh dan keluarganya dengan tetap memperhatikan perkembangan kemajuan dunia usaha.

Dengan demikian, makna bekerja dapat dilihat dari segi perorangan dan segi kemasyarakatan. Dilihat dari segi kemasyarakatan merupakan pekerjaan yang menghasilkan barang atau jasa guna memenuhi kebutuhan masyarakat. Terdapat hubungan antara sesama umat manusia. Adanya hubungan para pihak dalam memenuhi kebutuhan guna mempertahankan keberlangsungan hidupnya. Berkaitan dengan ketenagakerjaan musti adanya suatu perangkat bagi sarana perlindungan dan kepastian hukum bagi tenaga kerja. Baik bagi mereka yang akan atau sedang mencari pekerjaan atau yang sedang melaksanakan hubungan kerja maupun setelah berakhirnya hubungan kerja. Salah satu bentuk perlindungan dan kepastian hukum melalui pelaksanaan dan penerapan perjanjian kerja.

Perjanjian kerja menurut Undang-Undang Nomor 13 Tahun 2003 adalah perjanjian antara pekerja atau buruh dengan perusahaan atau pemberi kerja yang termuat syarat-syarat hak dan kewajiban para pihak. Perjanjian kerja pada dasarnya dibuat untuk mencegah terjadinya perselisihan atau sengketa yang dapat terjadi antara para pihak yang terlibat dalam suatu hubungan kerja yakni pihak pertama (perusahaan) dan pihak kedua (karyawan). ${ }^{1}$ Di dalam perjanjian kerja diletakkan segala hak dan kewajiban secara timbal balik antara pengusaha dan pekerja. Kedua belah pihak dalam melaksanakan hubungan kerja telah terikat pada kesepakatan di dalam perjanjian kerja maupun peraturan perundang-undangan yang

\footnotetext{
${ }^{1}$ Suhartoyo, S. (2019). Prinsip Persiapan Penempatan dan Perlindungan Tenaga Kerja Indonesia di Luar Negeri. Administrative Law \& Governance Journal, 2(3), 523 - 540. https://doi.org/10.14710/alj.v2i3.523 - 540
} 


\begin{tabular}{llrr}
\hline \hline Volume: & 2 & E-ISSN: & $2655-1942$ \\
Number: & 2 & Terbitan: & November 2019 \\
Page : & $361-369$ & & \\
\hline
\end{tabular}

berlaku.Pembangunan ketenagakerjaan harus diatur sedemikian rupa sehingga terpenuhi hak-hak dan perlindungan yang mendasar bagi tenaga kerja dan pekerja/buruh serta pada saat yang bersamaan dapat mewujudkan kondisi yang kondusif bagi pengembangan dunia usaha.

Pembangunan ketenagakerjaan mempunyai banyak dimensi dan keterkaitan. Keterkaitan itu tidak hanya dengan kepentingan tenaga kerja selama, sebelum dan sesudah masa kerja tetapi juga keterkaitan dengan kepentingan pengusaha, pemerintah, dan masyarakat. Untuk itu, diperlukan pengaturan yang menyeluruh dan komprehensif, antara lain mencakup pengembangan sumber daya manusia, peningkatan produktivitas dan daya saing tenaga kerja Indonesia, upaya perluasan kesempatan kerja, pelayanan penempatan tenaga kerja, dan pembinaan hubungan industrial.

Pembuatan perjanjian kerja harus memuat unsur dan syarat yang telah ditentukan didalam membuat perjanjian kerja agar dapat mempunyai kekuatan hukum yang sah diantara para pihak. Dalam melakukan pekerjaan dibedakan menjadi 2 (dua) macam, yaitu:1.Melaksanakan pekerjaan untuk dirinya sendiri, dan 2.Melakukan pekerjaan untuk dilaksanakan dalam suatu hubungan kerja, yang mana si pekerja mengharapakan upah dari orang lain yang bertindak sebagai pemberi kerja, di bawah perintah orang lain dan hasilnya pun untuk kepentingan orang lain bahwa dalam melakukan pekerjaan tersebut, hasil pekerjaan bukan untuk dirinya sendiri tetapi untuk orang lain.

Seiring berjalannya waktu terdapat beberapa perusahaan memberlakukan syarat tertentu yakni memasukkan klausul penahanan ijazah pekerja selama terjadi hubungan kerja dalam perjanjian kerja. Padahal dalam peraturan perundang-undangan di bidang ketenagakerjaan, termasuk Undang-Undang Nomor 13 Tahun 2003 tentang Ketenagakerjaan tidak mengatur boleh-tidaknya perusahaan menahan ijazah pekerja. Kasus penahanan ijazah ini ditangani oleh Badan Konsultasi Hukum Fakultas Hukum Universitas Diponegoro tahun 2019. Kasus ini bermula dari seorang pekerja diharuskan menyerahkan ijazah sebagai jaminan keberalngsungan oekerjaan pada PT. SINTAX (bukan nama asli). Setelah berkonsultasi dengan konsultas Konsultas pada Badan Konsultasi Hukum Fakultas Hukum Universitas Diponegoro menghasilakan rekomendasi tahapan penaganan. Untuk 


\begin{tabular}{llrr}
\hline \hline Volume: & 2 & E-ISSN: & $2655-1942$ \\
Number: & 2 & Terbitan: & November 2019 \\
Page : & $361-369$ & & \\
\hline
\end{tabular}

menjelaskan tahapan penaganan oleh Badan Konsultasi Hukum Fakultas Hukum Universitas Diponegoro, maka dalam tulisan ini akan menguraikan secara konseptual apa dan bagaimana pelanggaran terhadap hak tenaga kerja melalui penahanan ijazah oleh subjek hukum tertentu. Subjek hukum yang dimaskud adalah penyandang hak dan kewajiban dalam ranan hukum ketenagakerjaan di Indoensia.

\section{B. Pembahasan}

Tenaga kerja adalah penduduk dalam usia kerja (berusia 15-64 tahun) atau jumlah penduduk dalam suatu negara yang dapat memproduksi barang dan jasa jika ada permintaan terhadap tenaga kerja dan jika mereka mau berpartisipasi dalam aktifitas tersebut. ${ }^{2}$ Menurut Undang-undang Ketenagakerjaan Nomor 13 Tahun 2003 Pasal 1 angka 2 menjelaskan Tenaga kerja adalah setiap orang yang mampu melakukan pekerjaan guna menghasilkan barang dan/jasa untuk memenuhi kebutuhan sendiri maupun untuk masyarakat. Tenaga kerja mencakup penduduk yang sudah atau sedang bekerja, yang mencari pekerjaan dan yang melakukan kegiatan lain seperti bersekolah dan mengurus rumah tangga walaupun tidak bekerja, tetapi mereka secara fisik mampu dan sewaktu-waktu dapat ikut bekerja. ${ }^{3}$ Dilihat dari beberapa pengertian di atas dapat disimpulkan bahwa tenaga kerja merupakan orang mampu bekerja dan termasuk dalam usia kerja baik yang sedang bekerja maupun yang sedang tidak bekerja.

Pekerja/buruh adalah setiap penduduk dalam usia kerja yang melakukan kegiatan ekonomis, baik dalam hubungan kerja di perusahaan maupun di luar hubungan kerja seperti pekerja mandiri, pekerja keluarga dan pekerja di sektor informal lainnya ${ }^{4}$. Pekerja atau buruh merupakan bagian dari tenaga kerja yaitu tenaga kerja yang bekerja di dalam hubungan kerja, di bawah perintah pemberi kerja. ${ }^{5}$ Sedangkan menurut Undang-undang Nomor 13 Tahun 2003 Pasal 1 angka 3 menyebutkan bahwa, Pekerja/buruh adalah setiap orang yang bekerja menerima upah atau imbalan dalam bentuk lain . Jadi pekerja/buruh

\footnotetext{
${ }^{2}$ Mulyadi S, Ekonomi Sumber Daya Manusia dalam Perspektif pembangunan, Jakarta, Raja Grafindo Persada, 2006, halaman 26

3 Payaman J Simanjuntak, Pengantar Ekonomi Sumber Daya Manusia, edisi 2 ( Jakarta : Lembaga Penerbit FEUI, 1998), halaman 41

${ }^{4}$ Payaman J Simanjuntak, Manajemen Hubungan Industrial, (Jakarta : Pustaka Sinar Harapan, 2003), halaman 35

${ }^{5}$ Maimun, Hukum Ketenagakerjaan Suatu Pengantar, (Jakarta : Pradnya Paramita, 2003), halaman 14
} 


\begin{tabular}{llrr}
\hline \hline Volume: & 2 & E-ISSN: & $2655-1942$ \\
Number: & 2 & Terbitan: & November 2019 \\
Page : & $361-369$ & & \\
\hline
\end{tabular}

adalah tenaga kerja yang bekerja di dalam hubungan kerja di bawah perintah pengusaha/pemberi kerja dengan mendapatkan upah atau imbalan dalam bentuk lain.

\section{Hak Pekerja/Buruh}

Hak pekerja/buruh merupakan pemenuhan kewajiban pengusaha. Kewajiban pekerja/buruh adalah melakukan pekerjaan sesuai dengan penugasan pimpinan menurut disiplin kerja dan dalam waktu kerja yang telah ditentukan. Hak-hak pekerja/buruh adalah sebagai berikut: ${ }^{6}$ Hak mendapat upah atau gaji; Hak atas pekerjaan dan penghasilan yang layak bagi kemanusiaan; Hak bebas memilih dan pindah pekerjaan sesuai bakat dan kemampuannya; Hak atas pembinaan keahlian kejuruan untuk memperoleh serta menambah keahlian dan ketrampilan lagi; Hak mendapatkan perlindungan atas keselamatan, kesehatan serta perlakuan yang sesuai dengan martabat manusia dan norma agama; Hak mendirikan dan menjadi anggota perserikatan tenaga kerja; Hak atas istirahat tahunan.

Pekerja/buruh berhak memperoleh upah, tunjangan-tunjangan serta jaminan sosial lainnya, beristirahat, cuti, dan memperjuangkan haknya secara langsung melalui serikat pekerja/serikat buruh sebagai imbalan atas jasa kerja. Di samping itu pekerja/buruh berhak memperoleh berbagai jenis perlindungan: perlindungan tidak melebihi jam kerja tertentu termasuk jam dan hari istirahat serta cuti tahunan, perlindungan atas keselamatan dan kesehatan pekerja/buruh, perlindungan atas hak berserikat dan berunding dengan pengusaha, serta perlindungan upah dan penghasilan pada saat tidak mampu melakukan pekerjaan. ${ }^{7}$

\section{Kewajiban Pekerja/Buruh}

Kewajiban pekerja/buruh diatur dalam KUHP Pasal 1603 huruf a hingga d yang isinya adalah sebagai berikut : Buruh diwajibkan melakukan pekerjaan yang dijanjikan menurut kemampuannya yang sebaik-baiknya; Buruh diwajibkan sendiri melakukan pekerjaannya, tidak boleh digantikan oleh orang ketiga selain dengan izin majikannya/pengusaha; Buruh diwajibkan menaati aturan-aturan tentang hal melakukan pekerjaannya serta aturan-aturan yang ditujukan pada perbaikan tata tertib dalam perusahaan milik majikan/pengusaha; Buruh pada umumnya diwajibkan melakukan atau tidak melakukan sesuatu menurut sesuai dengan perintah majikan/pengusaha.

\footnotetext{
${ }^{6}$ Darwan Prinst, Hukum Ketenagakerjaan Indonesia, (Bandung : PT Citra Aditya Bakti, 2002), halaman 22

${ }^{7}$ Payaman Simanjuntak, Op.cit, halaman 2
} 


\begin{tabular}{llrr}
\hline \hline Volume: & 2 & E-ISSN: & $2655-1942$ \\
Number: & 2 & Terbitan: & November 2019 \\
Page : & $361-369$ & & \\
\hline
\end{tabular}

Kewajiban pekerja/buruh selanjutnya diatur dalam undang-undang yang lebih khusus yaitu Undang-Undang Nomor 13 Tahun 2003 Pasal 102 Ayat (2) menyebutkan : Dalam melaksanakan hubungan industrial, pekerja/buruh dan serikat pekerja/buruh mempunyai fungsi menjalankan pekerjaan sesuai dengan kewajibannya, menjaga ketertiban demi kelangsungan produksi, menyalurkan aspirasi secara demokratis, mengembangkan keterampilan, dan keahliannya serta ikut memajukan perusahaan dan memperjuangkan kesejahteraan anggota beserta keluarganya. Selain itu pekerja/buruh juga diwajibkan membayar ganti rugi dan denda apabila melakukan berbuatan pelanggaran yang disengaja sesuai dengan Pasal 95 Ayat (1) Undang-Undang Nomor 13 Tahun 2003 tentang Ketenagakerjaan yang menyebutkan bahwa pelanggaran yang dilakukan oleh pekerja/buruh karena kesengajaan atau kelalaiannya dapat dikenakan denda.

\section{Penahanan Ijazah Sebagai Jaminan}

Ketentuan dalam Undang-Undang Nomor 13 Tahun 2003 tentang Ketenagakerjaan tidak mengatur bolehtidaknya perusahaan menahan ijazah pekerja. Penahanan ijazah pekerja/karyawan oleh perusahaan, diperbolehkan, sepanjang memang menjadi kesepakatan antara kedua belah pihak. Kesepakatan antara pekerja dan pengusaha biasa dituangkan dalam perjanjian kerja yang mengikat pekerja dan pengusaha dalam hubungan kerja. 8

Permasalahan penahanan ijazah ini juga berkaitan erat dengan perjanjian kerja yang ditandatangani oleh pekerja dan perusahaan. Penahanan ijazah oleh pengusaha diperbolehkan sepanjang pekerja menyepakatinya dan pekerja masih terikat dalam hubungan kerja. Selama diatur dalam dalam perjanjian kerja secara jelas dan disepakati para pihak, maka hal tersebut diperbolehkan. karena perjanjian kerja bersifat otonom, yakni isinya dapatmemperjanjikan apapun selama memenuhi asas kebebasan berkontrak.

Jika melihat pada ketentuan Undang-Undang Ketenagakerjaan yakni Undang-Undang Republik Indonesia Nomor 13 Tahun 2003 beserta peraturan pelaksanaannya, tidak terdapat peraturan yang mengatur tentang penahanan ijazah asli. Hal ini mengakibatkan adanya kekosongan hukum terkait boleh atau tidaknya dilakukan penahanan ijazah. Akibat kekosongan hukum ini maka pengusaha melakukan penahanan ijazah asli pekerja sebagai syarat diterimanya pekerja untuk bekerja berdasarkan kebiasaan yang terjadi pada dunia kerja serta dengan dasar kebebasan berkontrak. Penahanan ijazah asli ini adalah sebuah bentuk 


\begin{tabular}{llrr}
\hline \hline Volume: & 2 & E-ISSN: & $2655-1942$ \\
Number: & 2 & Terbitan: & November 2019 \\
Page : & $361-369$ & & \\
\hline
\end{tabular}

pelanggaran Hak Asasi Manusia (HAM).10 Ketentuan dalam Undang-Undang Nomor 39 Tahun 1999 tentang Hak Asasi Manusia pada pasal 1 angka 1 dijelaskan bahwa, hak asasi manusia adalah seperangkat hak yang melekat pada hakikat dan keberadaan manusia sebagai makhluk Tuhan Yang Maha Esa dan merupakan anugerah-Nya yang wajib dihormati, dijunjung tinggi dan dilindungi oleh negara, hukum, pemerintah dan setiap orang demi kehormatan serta perlindungan harkat dan martabat manusia.

Dijelaskan dalam pasal 1 angka 6 bahwa pelanggaran atas hak asasi manusia adalah setiap perbuatan seseorang atau kelompok orang termasuk aparat negara baik disengaja maupun tidak disengaja atau kelalaian, membatasi, dan atau mencabut hak asasi manusia seseorang atau kelompok orang yang dijamin oleh Undang-undang ini, dan tidak mendapatkan, atau dikhawatirkan tidak akan memperoleh penyelesaian hukum yang adil dan benar, berdasarkan mekanisme hukum yang berlaku. Alasan bahwa penahanan ijazah melanggar Undang-Undang HAM ini adalah pertama, hak untuk meningkatkan taraf hidup, yang diatur pada pasal 9 ayat (1).

Wujud konkrit dari hak ini dapat berupa memilih pekerjaan lain dengan upah yang lebih baik untuk meningkatkan kesejahteraan buruh itu sendiri. Dengan ijazah yang ditahan oleh pengusaha, maka akibatnya menghilangkan kesempatan bagi buruh untuk mengajukan lamaran bekerja pada perusahaan lain yang menurutnya lebih baik. Kedua, hak untuk memperoleh, sebagaimana diatur pada pasal 12 dalam UU HAM. Dengan ijazah yang ditahan oleh pengusaha, maka akibatnya menghilangkan kesempatan bagi buruh yang berkeinginan untuk melanjutkan pendidikannya, misalnya ke universitas. Ketiga, hak untuk bebas memilih pekerjaan yang disukainya, sebagaimana diatur pada pasal 38 dalam UU HAM. Dengan ijazah yang ditahan oleh pengusaha, maka akibatnya menghilangkan kesempatan bagi buruh untuk berpindah pekerjaan sesuai dengan minat dan bakat yang dimilikinya. Sebagaimana diketahui bahwa salah satu syarat untuk mengajukan lamaran bekerja di perusahaan maupun untuk melanjutkan pendidikan adalah adanya ijazah asli. Sehingga ketiga hak tersebut tidak lagi mungkin didapatkan oleh buruh sebagai manusia, akibat praktek penahanan ijazah.

Apabila ijazah pekerja tetap ditahan dan tidak dikembalikan setelah adanya pemutusan hubungan kerja, maka upaya cara-cara kekeluargaan terlebih dahulu dapat dilakukan. Namun, apabila memang pihak perusahaan tidak mengembalikan ijazah, maka pekerja dapat menggugat perusahaan tersebut atas dasar perbuatan melawan hukum atau melaporkan ke 


\begin{tabular}{llrr}
\hline \hline Volume: & 2 & E-ISSN: & $2655-1942$ \\
Number: & 2 & Terbitan: & November 2019 \\
Page : & $361-369$ & & \\
\hline
\end{tabular}

polisi atas tuduhan penggelapan yang diatur dalam Pasal 372 KUHP. Penggelapan merupakan perbuatan mengambil barang milik orang lain sebagian atau seluruhnya) di mana penguasaan atas barang itu sudah ada pada pelaku, tapi penguasaan itu terjadi secara sah. Misalnya, penguasaan suatu barang oleh pelaku terjadi karena pemiliknya menitipkan barang tersebut. Atau penguasaan barang oleh pelaku terjadi karena tugas atau jabatannya, misalnya petugas penitipan barang. Tujuan dari penggelapan adalah memiliki barang atau uang yang ada dalam penguasannya yang mana barang/uang tersebut pada dasarnya adalah milik orang lain.

\section{Simpulan}

Berdasarkan uraian tersebut, maka simpulan kajian konsultasi hukum terkait dengan Pelanggaran Hak Tenaga Kerja Melalui Penahanan Ijazah Sebagai Jaminan: Perspektif Hak Asasi Manusia adalah bahwa tenaga Kerja sebagai pekerja dijamin melalui peraturan perundang undangan memiliki hak hak normatif, seperti hak untuk upah, jaminan sosial dan hak mendapatkan pekerjaan yang sesuai dengan keinginan. Penahanan ijazah oleh suatu sumbjek hukum baik indivisu ataupun perusahaan termasuk merupakan pelanggaran terhadap hak tenaga kerja. Pelanggaran terhadap hak tenagakerja tersebut berakibat pada adanya konsekuensi dari hubungan kerja antara keduabelah pihak. Maka hubungan kerja dapat dibatalkan jika ternyata penahanan ijazah benar adanya. 


\begin{tabular}{llrr}
\hline \hline Volume: & 2 & E-ISSN: & $2655-1942$ \\
Number: & 2 & Terbitan: & November 2019 \\
Page : & $361-369$ & & \\
\hline
\end{tabular}

\section{DAFTAR PUSTAKA}

Mulyadi S, Ekonomi Sumber Daya Manusia dalam Perspektif pembangunan, Jakarta, Raja Grafindo Persada, 2006

Payaman J Simanjuntak, Manajemen Hubungan Industrial, Jakarta, Pustaka Sinar Harapan, 2003

Maimun, Hukum Ketenagakerjaan Suatu Pengantar, Jakarta, Pradnya Paramita, 2003

Darwan Prinst, Hukum Ketenagakerjaan Indonesia, Bandung, PT Citra Aditya Bakti, 2002

Muhamad Azhar, Hukum Ketenagakerjaan, Bagian HAN FH UNDIP, 2019.

Suhartoyo, S. (2019). Prinsip Persiapan Penempatan dan Perlindungan Tenaga Kerja Indonesia di Luar Negeri. Administrative Law \& Governance Journal, 2(3), 523 - 540. https://doi.org/10.14710/alj.v2i3.523 - 540 